\title{
Deep seismic reflection study over the Vindhyans of Rajasthan: Implications for geophysical setting of the basin
}

\author{
B RAJENDRA PRASAD* and V VIJAYA RAO** \\ National Geophysical Research Institute, Hyderabad 500 00\%, India. \\ *e-mail: rajbitragunta@yahoo.com \\ **e-mail: vijayraov@yahoo.co.in
}

This paper presents results of high-resolution deep seismic reflection profiling of the Proterozoic Vindhyan basin of the Rajasthan area along the Chandli-Bundi-Kota-Kunjer profile. Seismic images have been used to estimate the thickness of Vindhyan strata as well as to understand the tectonic framework of the basin. The results are constrained by gravity, magnetic and magnetotelluric data. The study reveals gentle SE-dipping reflection bands representing the Vindhyan strata. The seismic sections depict gradual thickening of the Vindhyan succession towards southeast from Bundi. The velocities of the upper and lower Vindhyans are identified as $4.6-4.8 \mathrm{~km} / \mathrm{s}$ and $5.1-5.3 \mathrm{~km} / \mathrm{s}$. The NW limit of the Vindhyan basin is demarcated by the Great Boundary Fault $(\mathrm{GBF})$ that manifests as a $30 \mathrm{~km}$ wide NW dipping thrust fault extending to a depth of $30 \mathrm{~km}$.

\section{Introduction}

There have been many attempts over several decades to understand the stratigraphy, sedimentology and tectonic setting of the Proterozoic Vindhyan basin of central India based on outcrop geology. However, geophysical studies revealing the subsurface disposition of the Vindhyan strata and the nature of the basement are relatively meager (figure 1). Seismic reflection profiling is the most accurate among the geophysical methods to understand the subsurface structure of any region. Hence, a high resolution deep crustal seismic reflection study has been carried out along a $400 \mathrm{~km}$ long Nagaur-Jhalawar transect across the Aravalli-Delhi fold belt covering the important tectonic domains of the NW Indian shield under the deep continental studies program of DST (figure 2). The southern part of the transect traverses the Great Boundary Fault and the northwestern part of the Vindhyan basin is almost orthogonal to the regional strike. In this paper, we briefly review the results of previous geophysical investigations on the Vindhyan basin, and present new reflection data from the Chandli-Bundi-Kota-Kunjer profile, covering the Rajasthan sector of the basin. The details of other parts of the transect have been reported earlier (Tewari et al 1997; Rajendra Prasad et al 1998, 1999; Vijaya Rao et al 2000). The present study is the first of its kind aimed to delineate the configuration of the Vindhyan basin in the Rajasthan area and to determine velocity and thickness of the basin fill using the deep seismic reflection method. Additionally, it was planned to understand the nature and crustal structure of the bordering Great Boundary Fault and its relationship to the evolution of the Vindhyan basin.

\section{Tectonic framework}

The Vindhyan basin, located on the Bundelkhand craton in central India, is one of the largest Proterozoic sedimentary basins of India. The margins of the basin are demarcated by an arcuate thrust belt comprising the Mesoproterozoic AravalliDelhi Fold Belt (ADFB) and the Satpura orogenic belts (SB) referred to as the mid-Proterozoic

Keywords. Vindhyan basin; reflection band; Great Boundary Fault; Narmada-Son lineament.

J. Earth Syst. Sci. 115, No. 1, February 2006, pp. 135-147

(C) Printed in India. 


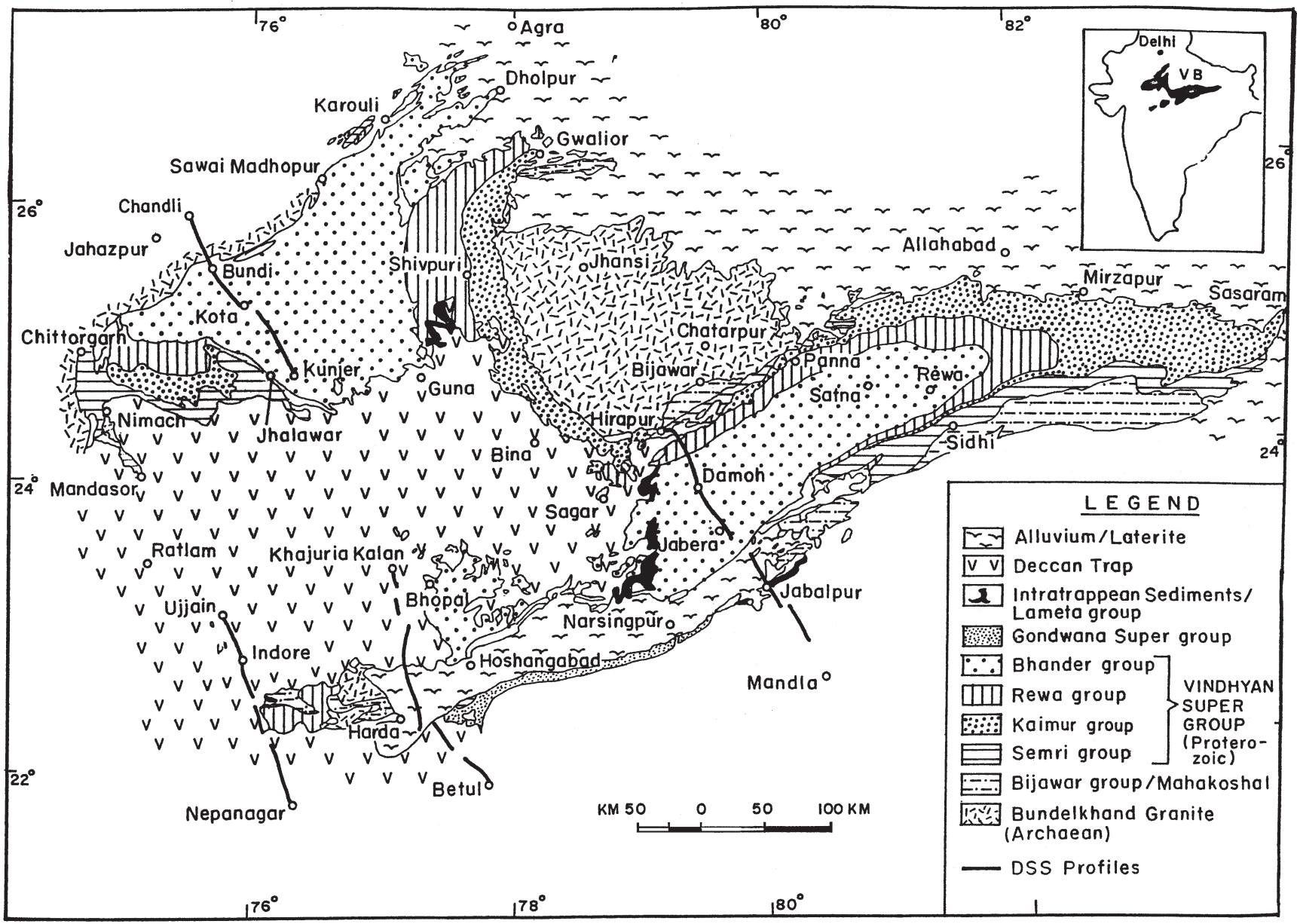

Figure 1. Geological map of the Meso-Neoproterozoic Vindhyan basin along with various DSS profiles.

mobile belt (MPMB of Radhakrishna and Naqvi 1986). It is believed that the basin was formed as a consequence of the collision of the Bundelkhand craton with the Deccan protocontinent in the south and the Mewar craton in the west during the early Mesoproterozoic period (Yedekar et al 1990; Raza et al 1993; Vijaya Rao and Reddy 2002).

A generalized tectonic map of the MesoNeoproterozoic Vindhyan basin is presented in figure 3. The Vindhyan basin is bounded in the NW by the Great Boundary Fault (GBF) and in the south by the Narmada-Son Lineament (NSL). The SW and NE parts of the basin are concealed under the Deccan traps and the Indo-Gangetic alluvium respectively. Two major sub-parallel faults namely, the Asmara lineament and the Jhalawar lineament are located in between the boundary faults (figure 3). These lineaments/faults seem to extend up to the Saurashtra coast in the west (Ramasamy 1995).

The Vindhyan basin predominantly comprises of shallow marine deposits. The maximum thickness of the basin fill reaches up to $5 \mathrm{~km}$ that accumulated during the prolonged history of sedimentation from 1700-700 Ma (Ray et al 2002). The Vindhyans are divided into lower and upper Vindhyans separated by a well marked unconfirmity. Major litho units of the Vindhyan basin consist of limestones, sandstones and shales. Major part of the basin consists of unmetamorphosed sediments providing suitable environments for the deposition of hydrocarbons. The occurrence of stromatolitic limestones in the basin proves the abundance of organic life in the Vindhyan sediments. Geochemical studies of some shales in the basin show $1.13 \%$ of total organic carbon suggesting the hydrocarbon potential of the basin. An exploratory well drilled to a depth of $3610 \mathrm{~m}$ at Jabera-1 anticlinal structure in the Son-valley Vindhyans yielded gas. Another well in the Vindhyan sediments of the Ganga basin's Tilhar-1 well indicated the presence of dissolved gas at a depth of $2000 \mathrm{~m}$ (Fuloria 1996).

The Vindhyan basin is variously regarded as a simple interior basin (Biswas et al 1993), rift basin (Jokhan Ram et al 1996) and foreland basin (Chakraborty and Bhattacharyya 1996). There are doubts regarding the continuity and similarity of tectonic evolution of the Son-valley and Rajasthan 


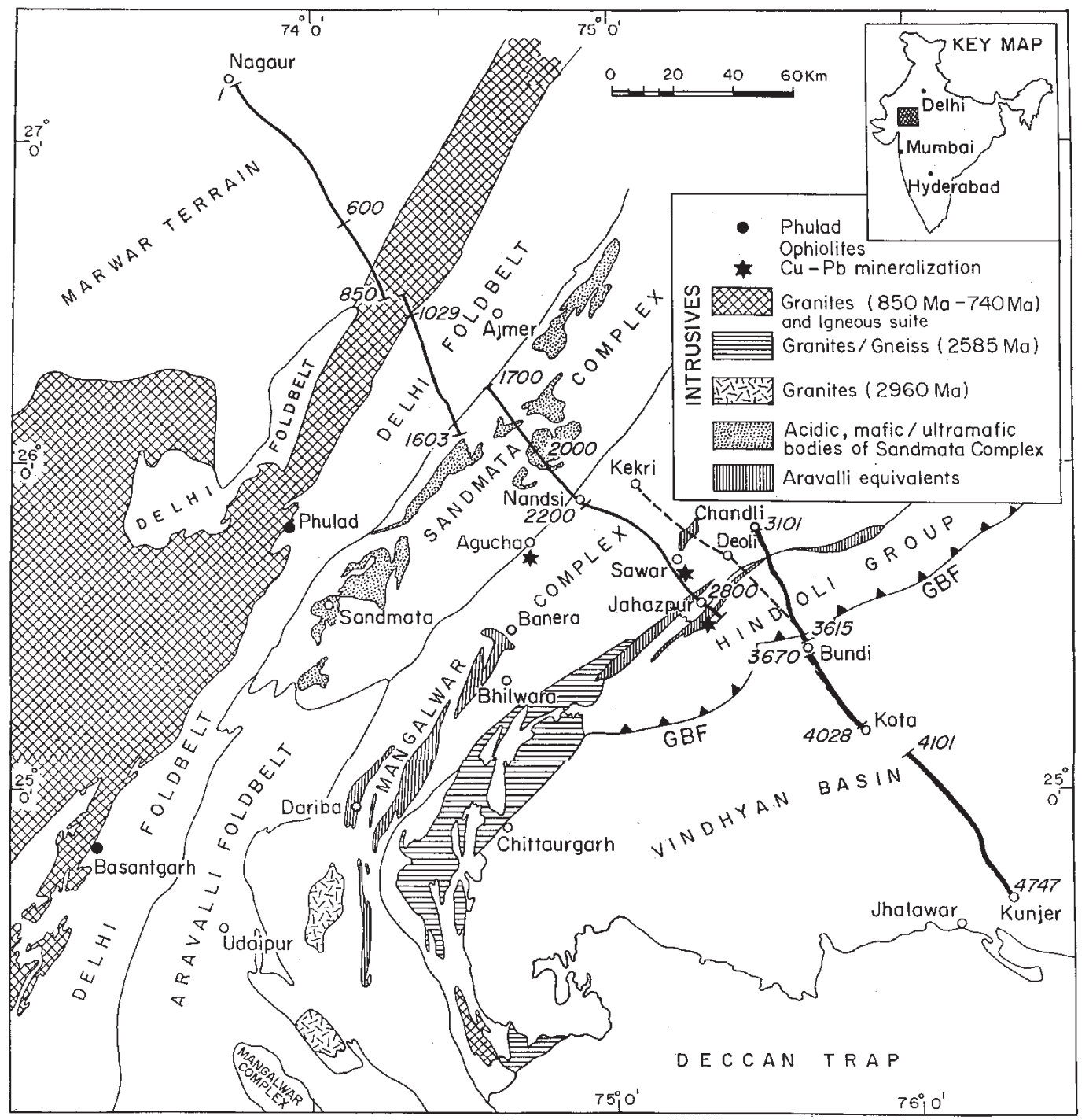

Figure 2. Nagaur-Kunjer seismic profile on a simplified geological map of the NW Indian shield. The Meso-Neoproterozoic Vindhyan basin is located in the SE part of the profile. Thick NW-SE line indicates present study area. Numbers along the profile are the shot point numbers used in reflection profiling. Location map of the magnetotelluric profile is shown with dotted lines. GBF: Great Boundary Fault (after GSI 1980; age data after Choudhary et al 1984).

Vindhyans (figures 1 and 3). Some researchers believe that there must have been two depocentres in a single basin with Bundelkhand massif acting as an extensive intrabasinal horst. Others believe that the Vindhyan basin was developed as a vast single basin, subsequently separated during the Phanerozoic. But, no consensus has emerged regarding the type of basin and its tectonic evolution. Seismic reflection study provides the high resolution structural details which are very essential to understand the nature of the basin.

\section{Geophysical framework of the Vindhyan basin}

Large tracts of the basin have been geologically mapped followed by extensive aeromagnetic surveys, detailed gravity and ground magnetic surveys. More seismic surveys were carried out in the Gangetic Vindhyans due to better hydrocarbon prospects compared with the Son-valley and the Rajasthan Vindhyans.

\subsection{Seismic studies}

Crustal seismic refraction/wide-angle reflection studies along the Hirapur-Mandla profile over the Son-valley Vindhyan basin show a gradual increase of thickness of the sediments from the Bundelkhand granitic massif in the north towards the Narmada-Son lineament in the south (Kaila et al 1989). A maximum of $5 \mathrm{~km}$ thick sediments are noticed at the NSL and their absence further south (figure 4). Thus, the seismic studies demarcated the southern boundary of the Vindhyan basin at 


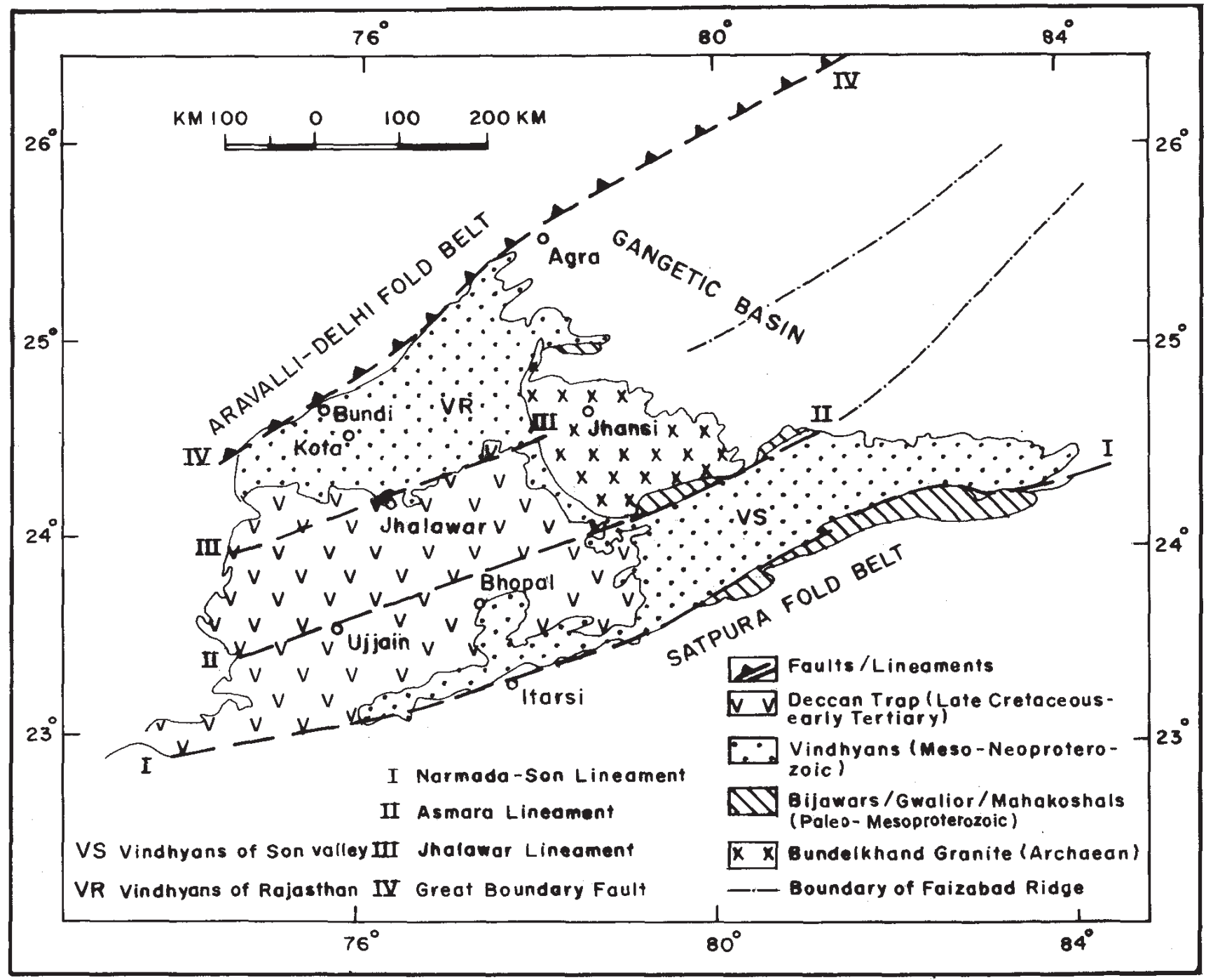

Figure 3. Simplified tectonic map of the Vindhyan Basin (modified after Ramasamy 1995; GBF after Tewari 1995; Boundary of Faizabad Ridge after Hari Narain and Kaila 1982).

the NSL. The seismic studies along the Khajuria Kalan-Pulgaon and Ujjain-Mahan profiles in the SW part of the Vindhyan basin (figure 1) indicate thin sediments at the basin margin and thickening away from it towards the interior of the basin (Kaila 1986). However, these studies were confined only nearer to the NSL and hence cannot be used to estimate the thickness of Vindhyans north of Ujjain and Bhopal.

Limited seismic studies were carried out for exploration of hydrocarbons in the Vindhyan basin as it is regarded as category-IV basin by ONGC. The studies were confined to the southern part in the Son-valley Vindhyans and the northern part for the Vindhyan sediments in the Ganga valley (Srivasthava et al 1983; Jokhan Ram et al 1996). A number of exploratory wells drilled through the Vindhyan sequence in the Ganga valley revealed that the Vindhyans are present below the Gangetic alluvium. Hari Narain and Kaila (1982) from the seismic studies have concluded that horst and graben tectonics were active during the deposition of the Vindhyan sediments.

\subsection{Magnetotelluric studies}

The magnetotelluric studies along the DamohMandla seismic profile (figure 1) in the Son-valley Vindhyan basin show a conductive crust under the Vindhyan sediments (Gokaran et al 2001). The conductive crust displays higher velocity $(6.5 \mathrm{~km} / \mathrm{s})$. Similar studies along the Deoli-Jhalawar seismic profile (figure 2) in the Rajasthan part of the Vindhyan basin also show a conductive crust below Vindhyan sediments (figure 5) at least to a depth of $10 \mathrm{~km}$ (Gokaran and Singh 2000). 


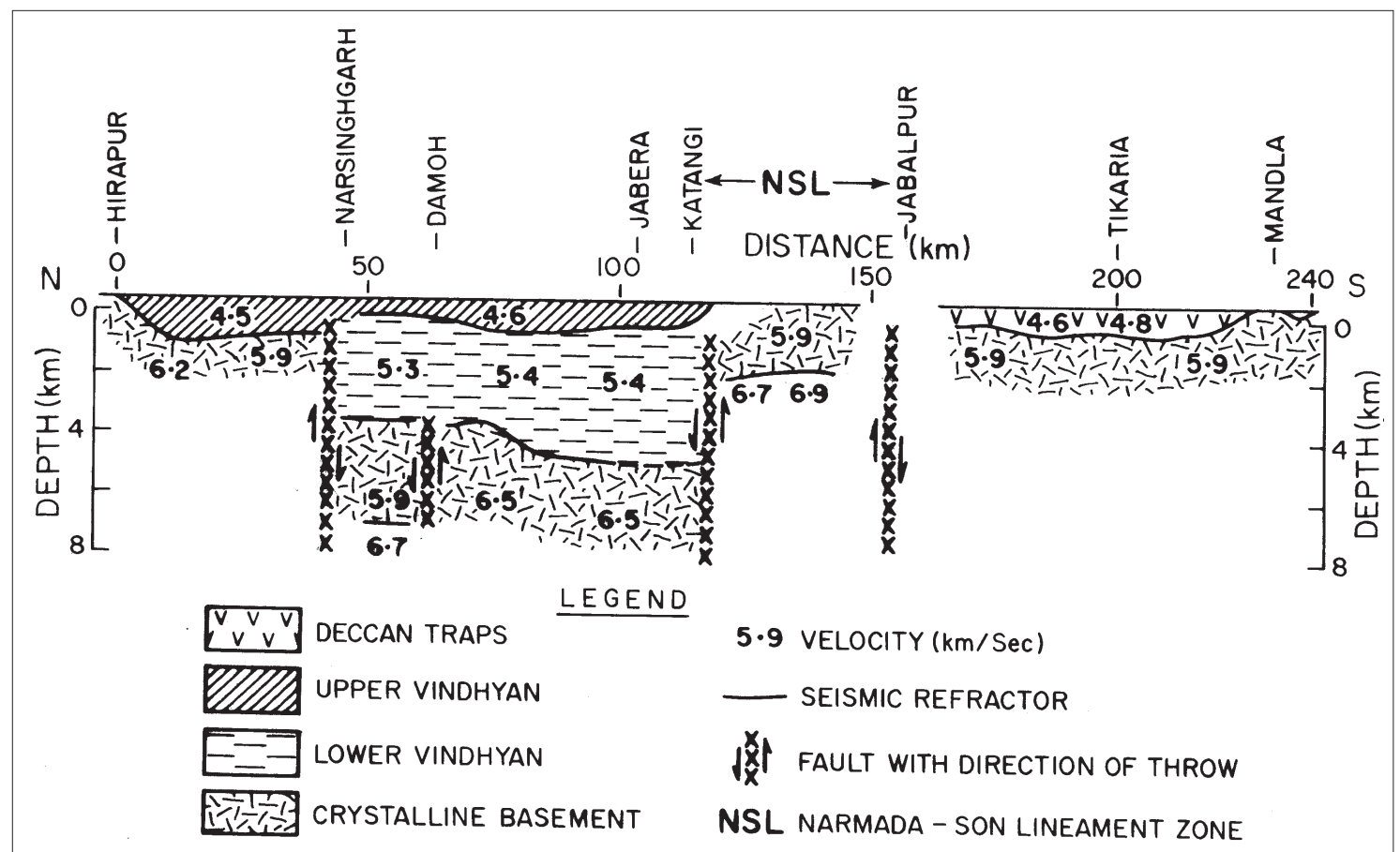

Figure 4. Basement depth section along the Hirapur-Mandla seismic profile of the Son-valley Vindhyan basin, located south of the Bundelkhand massif (after Kaila et al 1989). The northern most portion (near Hirapur) is located on the Bundelkhand granites.

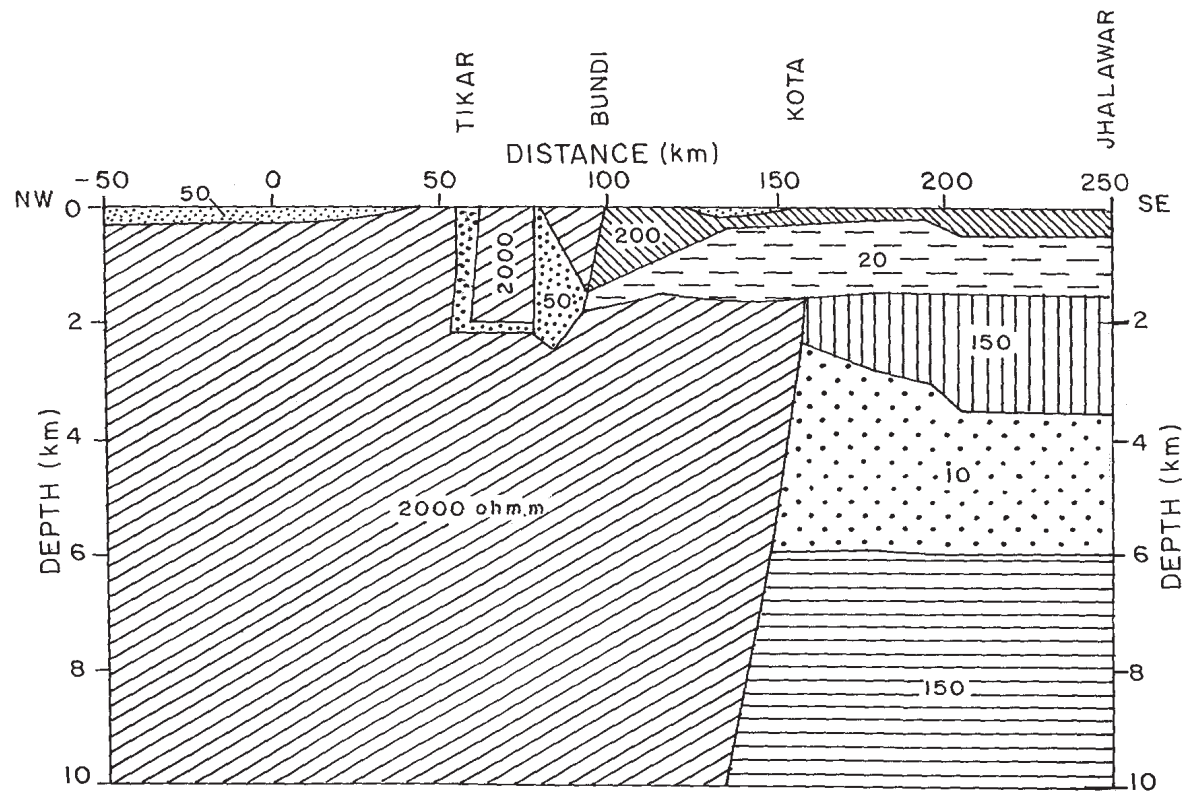

Figure 5. Geoelectrical section along the Bundi-Kunjer profile (after Gokaran and Singh 2000).

\subsection{Gravity and magnetic studies}

The Bouguer gravity map of the Vindhyan basin (NGRI, 1978) is presented in figure 6. The Vindhyan basin extending in the general NE-SW direction is characterized by the Bouguer gravity low, with a relief of $30-40 \mathrm{mGal}$. It is located between two arms of the Aravalli and Satpura horsts which are characterized by gravity high with a relief of 50-60 mGals.

The gravity and magnetic anomalies along the Bundi-Kunjer seismic profile (figure 2) in the NW part of the Vindhyan basin (Mishra et al 2000) are shown in figure 7 . Total intensity magnetic value gradually increases from $45,700-46,100 \mathrm{nT}$, an increase of $400 \mathrm{nT}$, along the seismic profile 


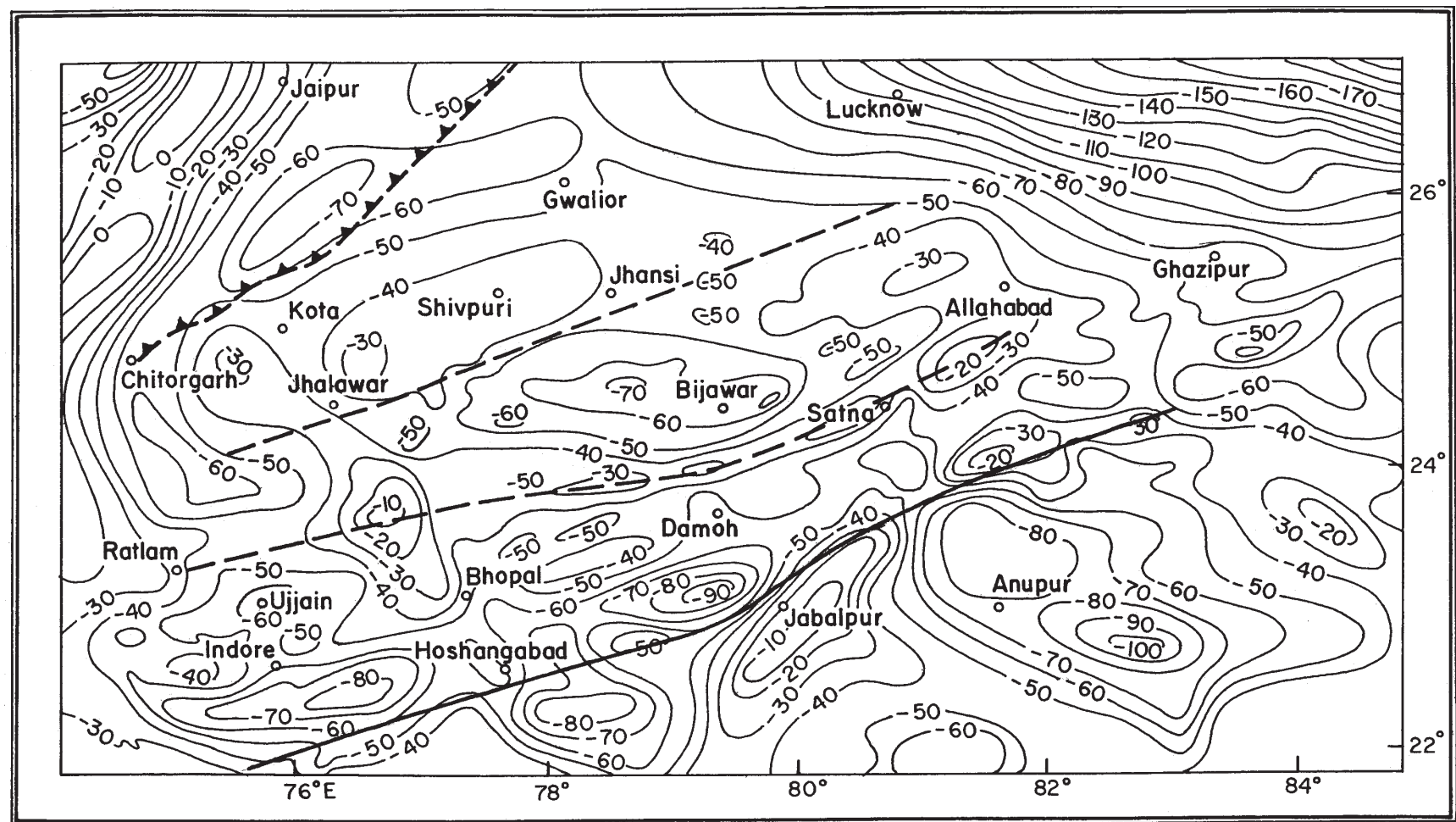

$-2 \mathrm{O}_{-3} \mathrm{P}$ Bouguer Gravity Contour (mGal)

$\mathrm{Km} 40$

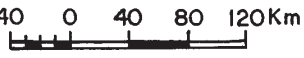

Figure 6. Bouguer gravity map of the Vindhyan basin and its adjoining regions (NGRI 1978). The dashed lines indicate the basement ridge. The thrust fault represents the GBF. The gravity low in the middle represents the Bundelkhand granites. The gravity high in the NW corresponds to Aravalli-Delhi Fold Belt and low in the NE represents the sediments of the Indo-Gangetic basin.
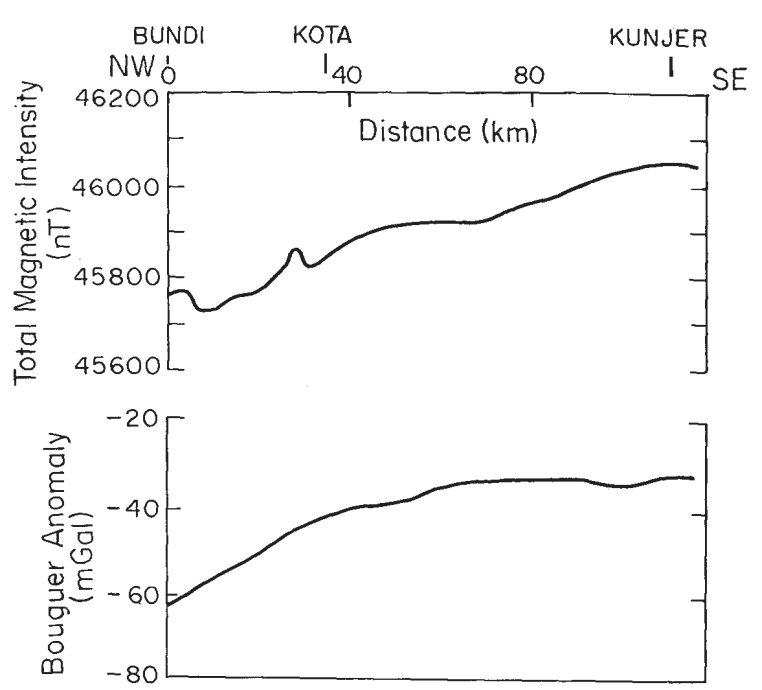

Figure 7. Total magnetic intensity and Bouguer gravity anomaly along the Bundi-Kunjer profile (after Mishra et al 2000).

from Bundi-Kunjer covering the Vindhyan basin. Similarly, the Bouguer gravity value also increases from $-60 \mathrm{mGal}$ to $-30 \mathrm{mGal}$, an increase of $30 \mathrm{mGal}$.

\section{Deep seismic reflection profiling in Rajasthan}

Deep crustal seismic reflection profiling was carried out along a $150 \mathrm{~km}$ long Chandli-Bundi-KotaKunjer profile traversing across the Mangalwar Complex, the Hindoli group and the Vindhyan basin, using the Common Depth Point (CDP) technique. The reflection data were acquired using $100 \mathrm{~m}$ shot and receiver spacing with $4 \mathrm{~ms}$ sampling interval using 120 channel DFS-V, digital equipment. $35 \mathrm{~kg}$ dynamite loaded in $25 \mathrm{~m}$ shot hole was used as the seismic source. A six-phone string of $4.5 \mathrm{~Hz}$ geophones was used as sensor at each location. Such a configuration provides an adequate bandwidth $(4.5-64 \mathrm{~Hz})$ for deep seismic reflection studies.

Reflection data are processed using the Geomaster software on the CDC Cyber 11/780 computer system. Processing involves a number of steps which convert the multi-offset shot domain seismic data to zero-offset domain. The field data of time-sequential format is converted into tracesequential format by demultiplexing. Amplitude balancing was carried out to enhance later weak signals to compensate for spherical divergence of 

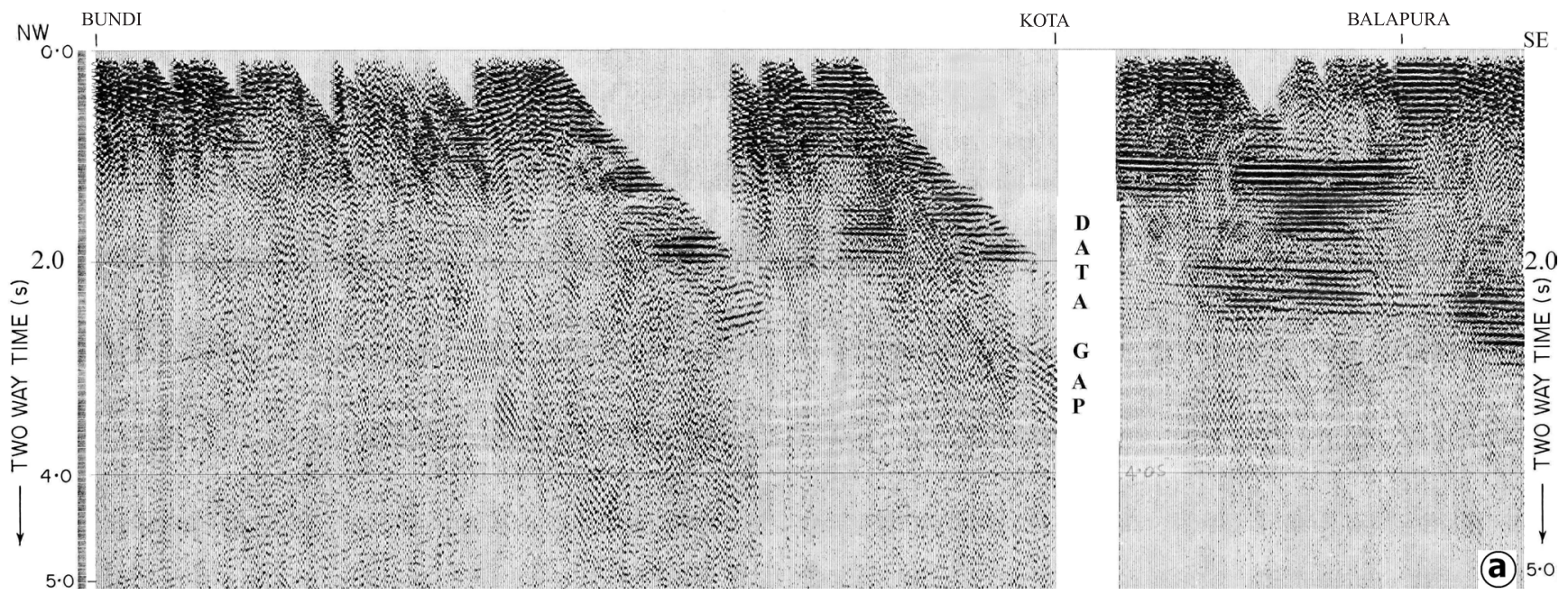

Figure 8(a). Shallow part of the seismic stack section (0-5 s TWT) along the Bundi-Balapura segment located in the NW part of the Vindhyan basin. The subhorizontal reflection band in the shallow part of the section represents the Vindhyan sediments. Note that the thickness of Vindhyan sediments increases from 1-3 sec TWT from NW to SE direction.

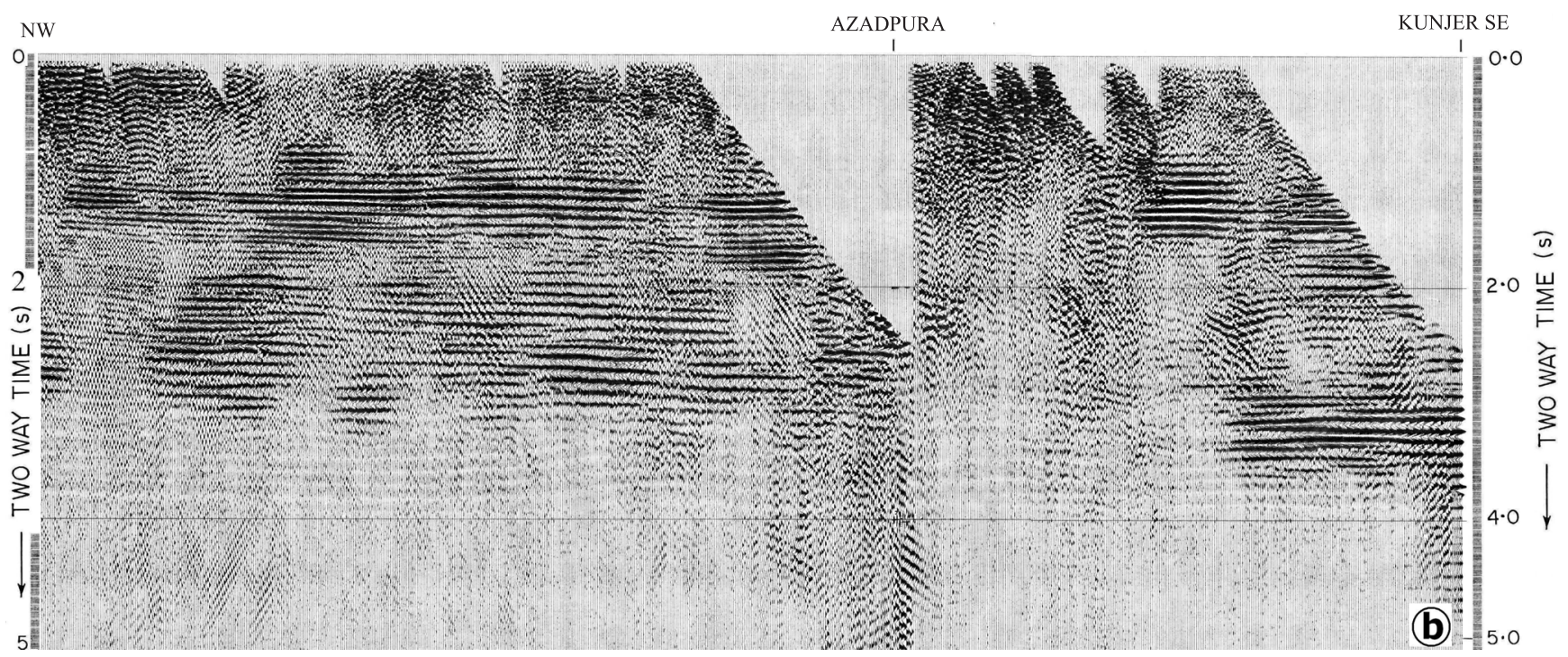

Figure $8(\mathrm{~b})$. Shallow part of the seismic stack section $(0-5 \mathrm{~s}$ TWT) along the Balapura-Kunjer segment located in the NW part of the Vindhyan basin. Note that the subhorizontal reflection band extends to 3.6 sec TWT in the SE part of the profile near Kunjer.

the seismic wave field. High amplitude refracted first arrivals were muted. Elevation and weathering correction were applied and the entire data were brought to a common datum level. Source-receiver geometry was generated and applied to convert the shot domain seismic data to CDP domain. Velocity analysis was carried out at every $5 \mathrm{~km}$ interval and the velocity model thus prepared was used to apply NMO correction. All traces of a CDP gather were stacked to enhance the signal-to-noise ratio, attenuate multiples and random noise.

The shallow seismic stack section of the Vindhyan basin up to $5 \mathrm{~s}$ two-way time (TWT) is presented in two parts as figure 8 (a and b). The stack section, which looks more like a geological cross-section, displays some of the prominent features of the region. The important feature of the seismic section is the presence of gently dipping SE reflection band from $1 \mathrm{~s}$ TWT at Bundi to $3.5 \mathrm{~s}$ TWT near Kunjer. No prominent reflections are observed beyond $3.5 \mathrm{~s}$ TWT. The reflectivity in the shallow part between Bundi-Kota is rather poor compared with the Kota-Kunjer part. To understand the tectonic evolution of a basin, it is essential to know the nature of its boundary. Accordingly, deep crustal seismic reflection data in 


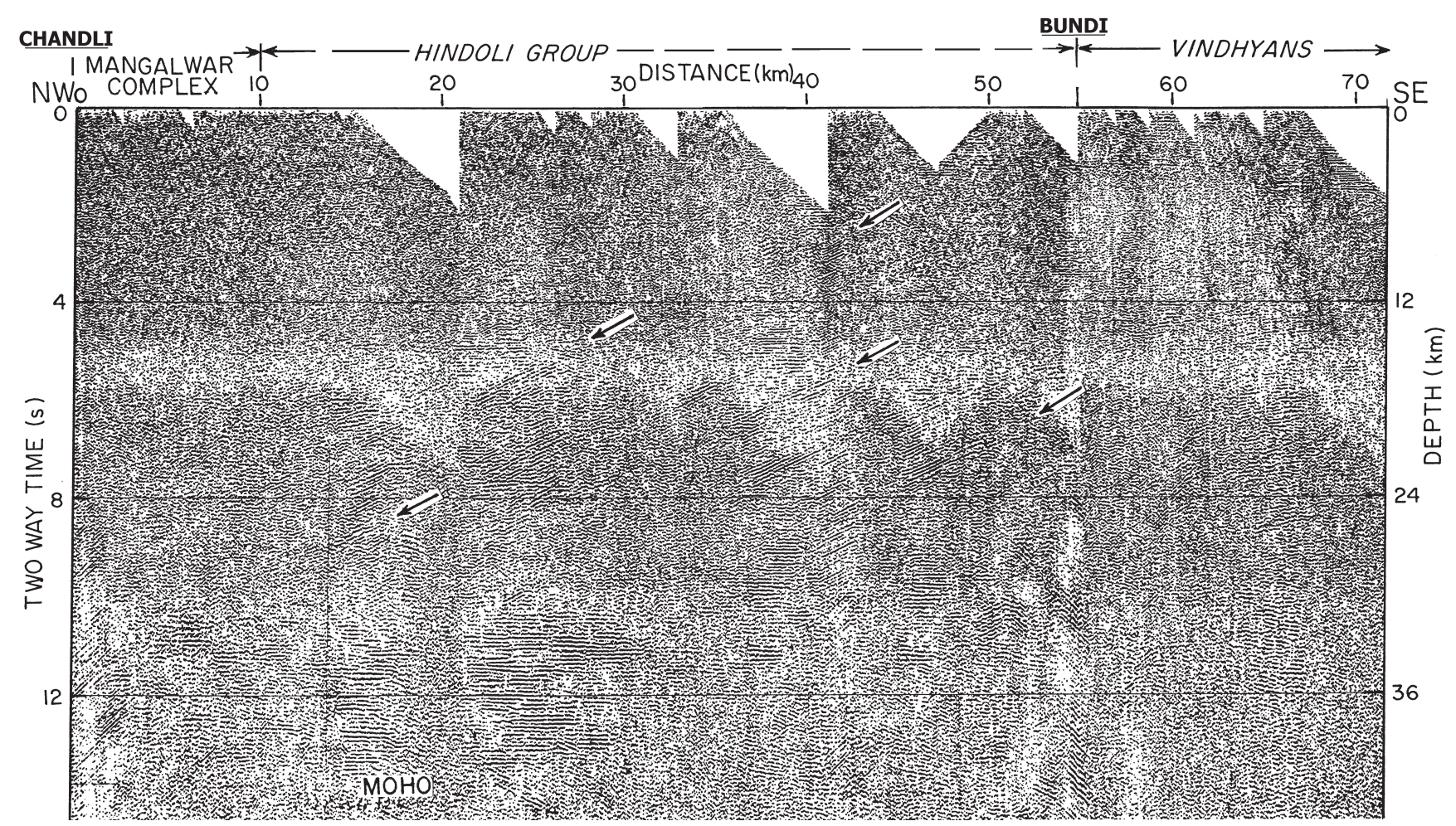

Figure 9. Seismic stack section representing the Great Boundary Fault. The NW dipping reflection band from Bundi extending to $10 \mathrm{~s}$ TWT $(\sim 30 \mathrm{~km}$ depth) represents the GBF. The depths on the right hand side are approximate.

the form of a stack section (up to $15 \mathrm{~s}$ TWT) is presented in figure 9. It covers the NW part of Vindhyan basin, its boundary and the surrounding area encompassing the Hindoli group (figure 2). The important feature of the stack section is the presence of a wide zone of NW dipping reflections with moderate reflectivity from $4 \mathrm{~s}$ TWT at Bundi to $10 \mathrm{~s}$ TWT further north. It almost covers the entire subsurface area of the Hindoli Group (figure 2).

The refracted first arrivals from the field records indicate two distinct velocities $(\mathrm{AB}$ and $\mathrm{BC}$, figure 10) which correspond to $4.6-4.8 \mathrm{~km} / \mathrm{s}$ and $5.1-$ $5.3 \mathrm{~km} / \mathrm{s}$ in $12 \mathrm{~km}$ offset range. Prominent reflections are observed even in the single fold field records as later arrivals up to $4.0 \mathrm{~s}$, which correlate with those observed in the shallow part of the stack section (figure $8 \mathrm{a}$ and b). In general the seismic wave field pattern is consistent and the data quality is good-very good in the Vindhyan basin.

\section{Discussion}

Subhorizontal and closely spaced reflections observed in the shallow part of the stack section (0.5-3.5 s TWT) represent Proterozoic Vindhyan sediments. The reflections are observed only between Bundi and Kunjer. No such reflections are observed to the west of Bundi, indicating absence of Vindhyans. The present study suggests that the western boundary of the Vindhyan basin is located at Bundi. Interestingly, the spatial location of the geologically mapped GBF coincides with that derived from the present seismic study. Thus, the GBF represents the northwestern boundary fault of the Vindhyan basin. The stack section also shows the reflection band that is confined to $1.0 \mathrm{~s}$ TWT at Bundi, gently extending to $3.5 \mathrm{~s}$ TWT near Kunjer indicating thin and thick sediments at the respective places. Thus, the Vindhyan basin is shallow at the GBF, the NW boundary of the Vindhyan basin, and deepens away from it in the SE direction towards the interior central part. As thick sediments are identified in the interior of the basin near Kunjer (figure 1), it is most likely that they may be extending further SE underneath the Deccan trap. The NW trend of the basin in the Rajasthan area is in contrast to the Son-valley Vindhyans, which show thick sediments at the NSL (Kaila 1986), the southern boundary of the basin, and thinning to the interior. These features provide important constraints in understanding the tectonic evolution of the basin.

The velocities of the top two layers of the region observed from the present study are $4.6-4.8 \mathrm{~km} / \mathrm{s}$ and $5.1-5.3 \mathrm{~km} / \mathrm{s}$. They represent the upper and lower Vindhyans respectively. Kaila et al (1989) from their refraction studies in the Son-valley Vindhyan basin along the Hirapura-Mandla profile (figure 1) have observed similar velocities for the 


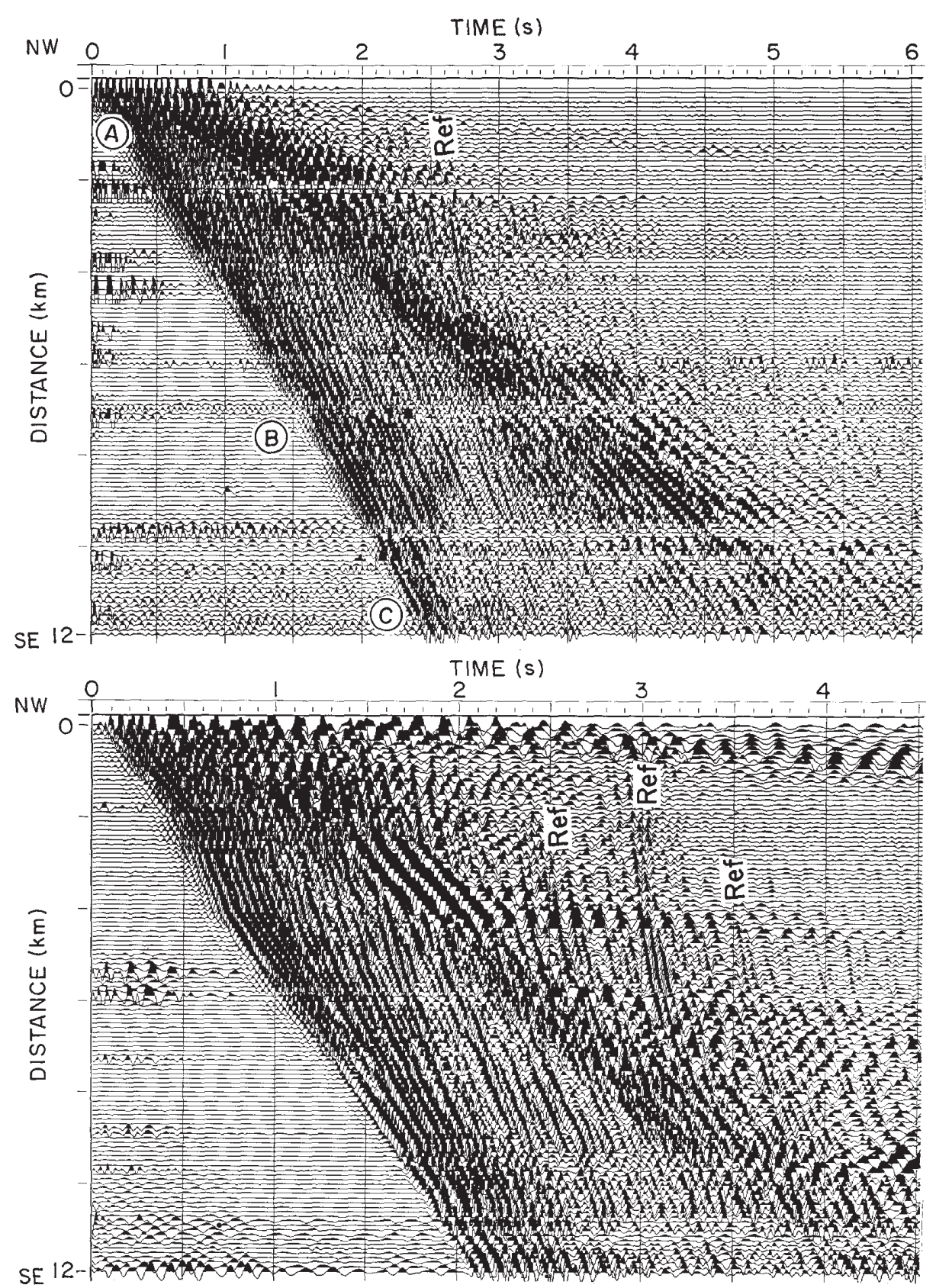

Figure 10. Specimen field record sections of the Rajasthan part of the Vindhyan basin. The refracted first arrivals, AB and $\mathrm{BC}$ with $4.8 \mathrm{~km} / \mathrm{sec}$ and $5.1 \mathrm{~km} / \mathrm{sec}$ velocities represent the Upper and Lower Vindhyans respectively. Later phases, Ref represents the reflections from the Vindhyan sediments.

upper and lower Vindhyans. The two-way travel time of the Vindhyan sediments (3.5 s TWT) when converted to depth using the observed $5.0 \mathrm{~km} / \mathrm{s}$ average velocity may represent a depth of $\sim 9 \mathrm{~km}$. It can be clearly seen from seismic stack sections (figures $8 \mathrm{a}$ and $\mathrm{b}$ ) that the thickness of the sediments gradually increase towards SE (away from GBF). But, the Bouguer gravity value gradually increases inspite of thicker sediments towards SE from a value of $-60 \mathrm{mGal}$ and reaches a maximum value of around $-30 \mathrm{mGal}$ at Kunjer. It shows a change in gravity value of $-30 \mathrm{mGal}$ from Bundi to Kunjer. Such an increase of the Bouguer gravity values from the GBF towards SE into the basin is not only confined to the present study area, but seems to be a regional feature as observed from the Bouguer gravity map of the region (figure 6).

The velocity and density of Vindhyan rocks are $4.6-5.3 \mathrm{~km} / \mathrm{s}$ and $2.50-2.56 \mathrm{~g} / \mathrm{cm}^{3}$ while that of crystalline basement is $5.9 \mathrm{~km} / \mathrm{s}$ and $2.7 \mathrm{~g} / \mathrm{cm}^{3}$ respectively. If the entire rock sequence up to $3.5 \mathrm{~s}$ TWT in the shallow part represents low density Vindhyans the gravity value should decrease instead of increasing towards SE 
(figure 7). Similarly, the total magnetic intensity value also increases from 45700 to $46100 \mathrm{nT}$ towards SE. The increase of magnetic values towards SE suggests high susceptibility rocks in between low susceptible or non-magnetic Vindhyans and crystalline basement. The maximum thickness of the Vindhyan sediments is reported to be $5 \mathrm{~km}$. In the absence of velocity information, the lower sequence from 5-10 km depth may be assumed to represent volcano-sedimentary sequence below Vindhyans. The metavolcanicmetasedimentary Hindoli group of rocks which are on the other side of GBF may be extending below Vindhyans. Such an interpretation explains the observed gravity and magnetic highs along the seismic profile. Such an interpretation is possible from the observed conductivity layer (figure 5) at this depth by magnetotelluric studies (Gokaran and Singh 2000). They may even represent high density lower crustal rocks thrusted up during the compressional regime that generated GBF or ADFB. In the absence of proper velocity structure, it is difficult to resolve the ambiguity. Mishra et al (2000) have suggested the presence of lower crustal high density $\left(2.8 \mathrm{~g} / \mathrm{cm}^{3}\right)$ rocks as the basement for Vindhyans.

The presence of thick sediments in the Vindhyan basin of Rajasthan area points towards the potential for hydrocarbon generation in the region. It derives support from the occurrence of oil and gas in the Jabera well (figure 1) of Son-valley Vindhyans and the Tilhar well of Gangetic Vindhyans respectively. Numerous commercial oil and gas fields have been discovered the world over in the Proterozoic Vindhyan equivalent basins such as the Lena Tunguska basin (Siberia), the Amadeus basin \& McArthur basin (Australia), the Sichuan basin (China), the Michigan, Wisconsin and Bayfield basins (USA).

The other prominent feature identified from the present study is the deep penetrating NW dipping reflection band $\left(\sim 30^{\circ}\right.$ dip) extending from 4 to $10 \mathrm{~s}$ TWT to the west of Bundi (figure 9). The nature of reflections indicate that it is a thrust fault developed in a compressional regime due to the convergence and collision of two crustal blocks namely, the Bundelkhand in the east and Mewar in the west. Conversion of two-way time $(10.0 \mathrm{~s}$ TWT) into depth indicates that the thrust fault extends approximately to a depth of $30 \mathrm{~km}$. The dimensions and the depth extension of the thrust fault suggests that thick-skinned tectonics were responsible for its evolution. It is one of the major thrust faults of the region. It separates the Vindhyan sediments from the volcano-sedimentary formations of the Hindoli group and represents the geologically mapped Great Boundary Fault of the region. Even though the GBF was geologically mapped, its deeper structure indicating nature of the fault, its direction of dip and depth extension was not available due to lack of appropriate geophysical investigations. The present seismic reflection study very clearly imaged these important details for the first time. The physical attributes of the GBF like its dimension, depth of penetration and its lateral continuity over a distance of $800 \mathrm{~km}$ from Chittorgarh to Agra, Bareily and beyond into the Himalayas in the NE-SW direction (Tiwari 1995) clearly suggests it has great significance in regional tectonic framework of the region. Thus, it can be inferred that GBF is a boundary fault not only confined to Rajasthan Vindhyans but also to the Gangetic Vindhyans located beneath the Indo-Gangetic alluvium in the north. Presence of Vindhyan sediments only to the east of GBF suggests that it was present earlier to the formation of the basin and was acting as a barrier with high elevation at the time of Vindhyan deposition. Recent $\mathrm{U}-\mathrm{Pb}$ zircon and Sr isotope data of the Vindhyan basin (Ray et al 2002) suggest that the Vindhyan sediments were deposited during 1700-700 Ma period. Thus, the GBF may be an earlier event, predating $1700 \mathrm{Ma}$.

During the process of collision high density lower crustal rocks might have been thrusted up and emplaced in the basin earlier to Vindhyan sedimentation. The GBF might have acted as a conduit to transport them to the surface. The sedimentary sequence of the Vindhyan basin and the adjacent NW dipping thrust fault representing the GBF are the important structural features which are related to each other. They provide clues to understand the tectonic evolution of the basin. A line drawing representing the above two features of the region is presented in figure 11 .

The broad structural features of the basin can be derived from the Bouguer gravity map of the Vindhyan basin (figure 6). It reveals a number of elongated highs and lows indicating probable horst and graben structure separating the Son-valley Vindhyans from Rajasthan Vindhyans. The difference in the structure could be due to recurrent rejuvenation of the NSL. The Bundelkhand granitic massif is associated with gravity low reaching a minimum value of $-70 \mathrm{mGal}$ in the middle. The Gangetic basin in the NE and Aravallis in the NW show Bouguer low and high respectively. The Aravalli trend clearly extends from Jaipur to Ratlam in the south. A $1100 \mathrm{~km}$-long gravity high extends from Ratlam to Patna in the ENE-WSW direction with a relief of $25 \mathrm{mGal}$ and joins many isolated gravity highs in the region. Qureshy and Warsi (1975) have attributed this high to the presence of high density volcano-sedimentary Bijawars below Vindhyans. Another linear structure also in the NNE-SSW direction can be observed passing 


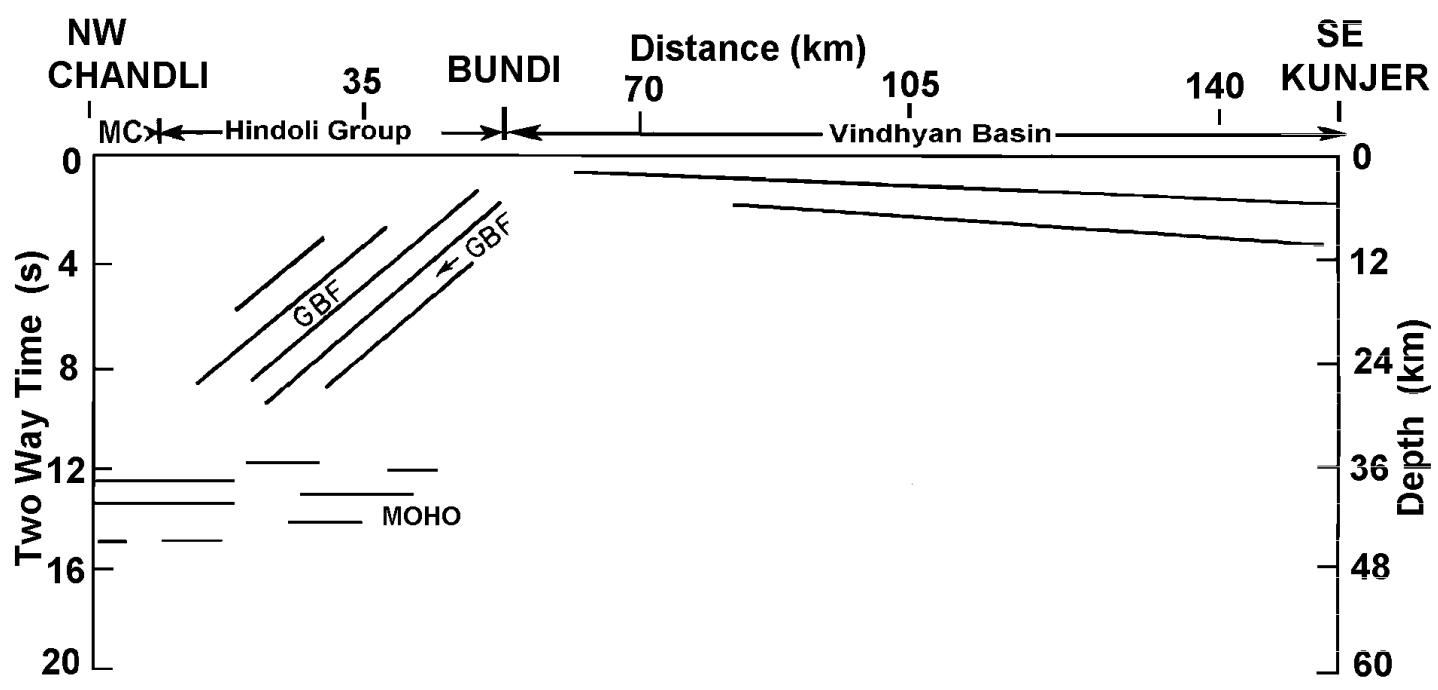

Figure 11. Simplified line drawing (derived from figures 8 and 9) representing the basin configuration of the Rajasthan Vindhyans and its boundary fault represented by Great Boundary Thrust Fault.

through Jhalawar-Jhansi and beyond into the Ganga valley. These two features coincide with the geologically observed Asmara and Jhalawar lineaments/faults (figure 3). Ghosh (1981) has postulated the region between these two faults as a probable basement ridge between Jhalawar and Ujjain with ENE-WSW orientation, which might have acted as a divide between the Son-valley and Rajasthan Vindhyans. Interestingly, this ridge is in line with the buried Faizabad ridge in the Ganga valley and may represent its extension in the SW. The Bundelkhand massif (2500 Ma) is located in the middle of this ENE-WSW trending ridge and is in line with it.

Another important feature of the gravity map is a horst type of structure in the NW-SE direction from Ujjain-Bhopal to the GBF covering the region between Chittorgarh and Bundi, marked by gravity high. It is almost perpendicular to the Aravalli orogenic trend. Banerjee and Singh (1981) from their geological studies have suggested the presence of a ridge near Bundi, which may be responsible for the formation of two basins, one near Chittorgarh and another near Karauli area (figure 1). This ridge coincides with the horst structure observed from gravity data.

A comparison of gravity, magnetic and magnetotelluric studies of the Rajasthan and the Son-valley Vindhyans suggests many similarities for these regions. Airborne magnetic and ground studies over the Son-valley Vindhyans reveal several large magnetic anomalies representing the horst and graben structure of the Paleoproterozoic Bijawar sediments, which form the basement for the Vindhyan sediments (Mishra 1987).
The gravity high observed over the Son-valley Vindhyans (figure 6) could be due to the presence of high density Bijawar formations (Verma and Banerjee 1992). Similar gravity and magnetic highs are also observed over the Rajasthan Vindhyans (figure 7). Resistivity and magnetotelluric studies indicate high conductive rocks below high resistive Vindhyans in both areas of the basin (Gokaran et al 2001). Geophysical signatures such as low resistivity, high density and high susceptibility covering a wide area of the region are attributed to the presence of the volcanogenic Bijawar sediments. Thus, it can be speculated that the Bijawar and Gwalior basins (figures 1 and 3 ) or their equivalents may be covering a wider area under the Vindhyan sediments to the south as well as to the west.

The velocity structure of the Son-valley Vindhyans (figure 4) indicates a high velocity layer $(6.5-6.7 \mathrm{~km} / \mathrm{s})$ just below Vindhyans, instead of the normal crystalline basement with $5.9 \mathrm{~km} / \mathrm{s}$ velocity. This high velocity layer also exhibits high conductivity (200 ohm.m). Such an anomalous structure is attributed to the presence of lower crustal mafic rocks or granulites just below the Vindhyan sediments (Tewari et al 2001). Such an emplacement is related to the collision of Bundelkhand craton with the Dharwar protocontinent (Rajendra Prasad and Vijaya Rao 2005).

The above evidence suggests that the Paleoproterozoic Bijawar is the oldest formation of the area that surrounds the Bundelkhand granite to the north as well as to the south (figure 1). High density lower crustal rocks might have been emplaced over the Bundelkhand craton during its collision with the Mewar craton and the Dharwar 
protocontinent, over the earlier Bijawars or its equivalent Hindoli group of rocks. Subsequently, Vindhyan sedimentation took place.

\section{Conclusions}

Seismic reflection images suggest that the Great Boundary Fault is a $30 \mathrm{~km}$-wide NW dipping thrust fault, which extends to a depth of $30 \mathrm{~km}$. It represents the NW boundary of the Proterozoic Vindhyan basin. The thickness of the Vindhyan succession increases away from the GBF towards southeast. This is in contrast to the Sonvalley Vindhyans, which show thick sediments at the southern boundary of the basin (NSL) and thinning to the interior. The present study suggests that the Great Boundary Fault evolved much earlier than $1700 \mathrm{Ma}$ and before the formation of the Vindhyan basin. A basement ridge separates the Son-valley Vindhyans from the Rajasthan Vindhyans.

\section{Acknowledgements}

We thank Dr. V P Dimri, Director, NGRI for permission to publish this work and Dr. H C Tewari, Emeritus Scientist for his encouragement. We are grateful to anonymous reviewers and Prof. Chandan Chakraborty for their useful suggestions. We thank Dr. Jyotiranjan S Ray for providing this opportunity to present our results. We also thank M Shankaraiah and B P S Rana for their help with the drawings.

\section{References}

Banerjee A K and Singh H J M 1981 Paleogeography and sedimentation of Vindhyans in eastern Rajasthan; Misc. Publ. Geol. Surv. India 50 89-94.

Biswas S K, Bhasin A L and Jokhan Ram 1993 Classification of Indian sedimentary basins in the framework of plate tectonics; In: Proc. second seminar on petroliferous basins of India (ed.) Biswas S K (Dehradun: Indian Petroleum Publishers) 11046.

Chakrabarthy C and Bhattacharyya A 1996 The Vindhyan basin: an overview in the light of current perspectives; In: Recent advances in Vindhyan geology (ed.) Ajit Bhattacharya, Geol. Soc. India Memoir 36 301-312.

Choudhary A K, Gopalan K and Anjaneya Sastry C 1984 Present status of geochronology of the Precambrian rocks of Rajasthan; Tectonophysics 105 131-140.

Fuloria R C 1996 Geology and hydrocarbon prospects of the Vindhyan sediments in Ganga valley; In: Recent advances in Vindhyan geology (ed.) Ajit Bhattacharya, Geol. Soc. India Memoir 36 235-256.

Geological Survey of India 1980 Lithostratigraphic map of Aravalli region (southern Rajasthan and north Gujarat).

Ghosh D B 1981 The Vindhyan basin in Bundelkhand Son valley region; Misc. Publ. Geol. Surv. India 50 75-88.
Gokaran S G, Rao C K, Gautam Gupta, Singh B P and Yamashita M 2001 Deep crustal structure in central India using magnetotelluric studies; G. J. Int. 144 685-694.

Gokaran S G and Singh B P 2000 Magnetotelluric techniques; In: Research Highlights in Earth System Science (eds) Varma O P and Mahadevan T M, A Publication of DST, Govt. of India, New Delhi, 1 123-142.

Hari Narain and Kaila K L 1982 Inferences about the Vindhyan basin from geophysical data; In: Geology of Vindhyachal (eds) Valdiya K S, Bhatia S B and Gaur V K, (Delhi: Hindustan Publishing Corporation) pp. 179-192.

Jokhan Ram, Shukla S N, Parmanik A G, Varma B K, Gyanesh Chandra and Murty M S N 1996 Recent investigations in the Vindhyan basin: Implications for the basin tectonics; In: Recent advances in Vindhyan geology (ed.) Ajit Bhattacharya, Geol. Soc. India Memoir 36 267-286.

Kaila K L 1986 Tectonic framework of Narmada-Son lineament: A continental rift system in central India from deep seismic soundings, In: Reflection Seismology: A global perspective (eds) Brazangi $\mathrm{M}$ and Brown $\mathrm{L}$, AGU, Washington, USA, Geodynamic series 13 pp.

Kaila K L, Murthy P R K and Mall D M 1989 The evolution of the Vindhyan basin vis-à-vis the Narmada-Son lineament, Central India, from deep seismic soundings; Tectonophysics 162 277-289.

Mishra D C 1987 Bijawar and Vindhyan tectonics of central India from airborne magnetics and ground geophysical surveys; Geol. Soc. India Memoir 6 357-367.

Mishra D C, Singh B, Tiwari V M, Gupta S B and Rao M B S V 2000 Two cases of continental collisions and related tectonics during the Proterozoic period in Indiainsights from gravity modeling constrained by seismic and magnetotelluric studies; Precamb. Res. 99 149-169.

NGRI 1978 Gravity series maps of India, NGRI/GPH 1-5.

Qureshy M N and Warsi W E K 1975 Role of regional gravity surveys in a concept-oriented exploration programme; J. Geol. Soc. India 16 44-54.

Radhakrishna B P and Naqvi S M 1986 Precambrian continental crust of India and its evolution; J. Geology 94 145-166.

Rajendra Prasad B, Tewari H C, Vijaya Rao V, Dixit M M and Reddy P R 1998 Structure and tectonics of the Proterozoic Aravalli Delhi Fold Belts in the NW India from deep seismic reflection studies; Tectonophysics $\mathbf{2 8 8}$ 31-41.

Rajendra Prasad B, Vijaya Rao V and Reddy P R 1999 Seismic and magnetotelluric studies over a crustal scale fault zone for imaging a metallogenic province of Aravalli Delhi Fold Belt region; Curr. Sci. 76 1027-1031.

Rajendra Prasad B and Vijaya Rao V 2005 Seismic Imaging of Indian Continental Crust; In: Recent Advances in Earth Sciences in India (eds) Arora B R and Dubey A K, J. Himalayan Geology 26 125-138.

Ramasamy S M 1995 Lineament analysis and stress modeling of Vindhyan basin, Rajasthan, India; In: Continental crust of northwestern and central India (eds) Sinha-Roy S and Gupta K R, Geol. Soc. India Memoir 31 279-310.

Ray J S, Martin M W, Veizer J and Bowring S A 2002 U-Pb zircon dating and Sr isotope systematics of the Vindhyan Supergroup, India; Geology 30 131-134.

Raza M, Jafri S G, Alvi S H and Khan M S 1993 Geodynamic evolution of Indian shield during Proterozoic: evidence from mafic volcanic rocks; J. Geol. Soc. India 41 455-469.

Srivastava B N, Rana M S and Varma N K 1983 Geology and petroleum prospects of the Vindhyan basin; In: Petroleferous basins of India, Petroleum Asia Journal, Dehradun 6(4) 179-189. 
Tewari H C, Dixit M M, Rao N M, Venkateswarlu N and Vijaya Rao V 1997 Crustal thickening under the Paleo/mesoproterozoic Delhi Fold Belt in NW India: Evidence from deep reflection profiling; Geophys. J. Int. 129 $657-668$.

Tewari H C, Murthy A S N, Prakash Kumar and Sridhar A R 2001 A tectonic model of the Narmada region; Curr. Sci. 80 873-878.

Tiwari S 1995 Extension of the Great Boundary Fault of Rajasthan in Ganga valley; In: Continental crust of NW and Central India (eds) Sinha-Roy S and Gupta K R, Geol. Soc. India Memoir 31 311-328.

Verma R K and Banerjee P 1992 Nature of continental crust along the Narmada-Son lineament inferred from gravity and deep seismic sounding data; Tectonophysics 202 375-397.

Vijaya Rao V, Rajendra Prasad B, Reddy P R and Tewari H C 2000 Evolution of Proterozoic Aravalli Delhi fold belt in the northwestern Indian shield from seismic studies; Tectonophysics 327 109-130.

Vijaya Rao V and Reddy P R 2002 A Mesoproterozoic Supercontinent: Evidence from the Indian Shield, In: Special volume on Mesoproterozoic Supercontinent (eds) Rogers J J W and Santosh M, Gondwana Research 5 63-74.

Yedekar D B, Jain S C, Nair K K K and Dutta K K 1990 The central Indian collision suture; Geol. Surv. India, Spec. Publ. 28 1-43. 